\title{
ZNAČILNOSTI PUBLICIRANJA NA PODROČJU GOZDNO-LESNE VERIGE IN NJIHOV VPLIV NA VREDNOTENJE PODROČIJ V SKLOPU EVALVACIJ RAZISKOVALNIH DOSEŽKOV - PREGLED OBJAV PUBLISHING CHARACTERISTICS IN THE FIELD OF WOOD VALUE CHAIN AND THEIR INFLUENCE ON THE ASSESSMENT OF SCIENTIFIC FIELDS IN THE RESEARCH EVALUATION POLICY - LITERATURE OVERVIEW
}

\author{
Maja PETEH ${ }^{1}$, Primož JUŽNIČ
}

(1) Gozdarska knjižnica - Gozdarski inštitut Slovenije in Univerza v Ljubljani, Biotehniška fakulteta, Oddelek za gozdarstvo in obnovljive gozdne vire, Ljubljana, Slovenija, maja.peteh@gozdis.si

(2) Univerza v Ljubljani, Filozofska fakulteta, Oddelek za bibliotekarstvo, informacijsko znanost in knjigarstvo, Ljubljana, Slovenija, primoz.juznic@ff.uni-lj.si

\begin{abstract}
IZVLEČEK
Prispevek prinaša pregled bibliometrijskih raziskav na področjih gozdarstva, lesarstva in papirništva ter postavlja v ospredje predvsem tiste posebnosti publiciranja, ki vplivajo na rezultate evalvacijskih procesov in posledično na razvoj področij. Osredotoča se na značilnosti objavljanja v znanstvenih revijah zaradi njihove vloge pri razvoju znanstvene discipline, področja in strokovne terminologije. Četudi gozdarstvo, lesarstvo in papirništvo sestavljajo gozdno lesno verigo, raziskave večinoma zajemajo le gozdarstvo in ugotavljajo široko interdisciplinarnost področja na eni strani in ozko usmerjenost raziskav. Primerjave objav znotraj gozdno lesne verige otežuje tudi vpliv različnih šifrantov znanosti, kar vpliva tudi na položaj teh področij znanosti. Zajete raziskave se večinoma osredotočajo na objave v revijah, indeksiranih v zbirkah WoS in Scopus, revije pa posamezne zbirke združujejo v posamezna področja. Nekaj raziskav prinaša tudi ugotovitve na ravni posameznih ustanov ali držav. Objavljanje znanstvenih člankov s teh področij ima velik vpliv na nadaljnji razvoj in tudi obstoj revij, predvsem revij manjših jezikovnih skupin. Velik delež gozdarskih objav je najti v revijah drugih znanstvenih področij, kar nakazuje tako na veliko interdisciplinarnost področja in sodelovanje avtorjev različnih področij kot tudi na določen vpliv sistema vrednotenja raziskovalnih dosežkov.
\end{abstract}

Ključne besede: bibliometrija, gozdarstvo, lesarstvo, papirništvo, raziskovalna politika, vrednotenje raziskovalnih dosežkov

\begin{abstract}
This article presents an overview of bibliometric research in the scientific fields of forestry, wood and paper sciences and highlights the characteristics of publishing in these areas, particularly those that affect the results of the evaluation process and, consequently, the development of these fields. Articles published in scholarly journals are considered important for the development of the scientific field and professional terminology, therefore the review focuses mainly on the specifics in the area of scientific publishing. Although forestry, wood and paper science comprise a single wood value chain, publications mainly cover only the forestry as a result of the interdisciplinary areas, different science classification schemes, narrow research areas, their role in the society. Research work under study focuses mainly on the publications indexed by citation databases WoS and Scopus. Some studies also present the findings on the level of individual institutions or countries. Publication of scientific papers in the field of forestry has an important impact on further development and continuation of journals in this field; especially in less common languages. An important part of articles in these fields is published in the journals which are not classified as forestry-associated indicating interdisciplinarity of the fields, cooperation between authors from different areas, as well as the impact of the evaluation policy on publishing patterns.
\end{abstract}

Key words: bibliometrics, forestry, wood technology, paper technology, research policy

\section{UVOD}

\section{INTRODUCTION}

Raziskovanje značilnosti publiciranja posameznega znanstvenega področja nam podaja svojevrsten vpogled v potek raziskovanja in omogoča raznoliko vrednotenje: kvantitativno vrednotenje objav, ugotavlja- nje njihovega vpliva na nadaljnje raziskave in vpliv na razvoj družbe v lokalnem in mednarodnem okolju. $\mathrm{V}$ naši raziskavi smo se omejili na gozdarstvo, lesarstvo in papirništvo, vede t. i. gozdno-lesne verige. Gozdnolesna veriga povezuje znanosti (raziskave) o gozdu, gozdarstvo kot stroko, ki usmerja urejanje gozdov, iz- 
koriščanje in, logistiko izkoriščanja gozdov, povezuje pa tudi vse industrije, ki se ukvarjajo s predelavo lesa do končnega izdelka. Interdisciplinarnost lesarstva in papirništva je treba razumeti tudi širše, izven kmetijskih, agronomski ali biotehniških ved, saj sta to vedi o materialih.

$\mathrm{Z}$ raziskovanjem kvantitativnih vidikov informacijskih virov $\mathrm{v}$ vseh pojavnih oblikah in $\mathrm{v}$ vseh okoljih se ukvarja priznana kvantitativna raziskovalna metoda bibliometrija, katerih rezultate uporabljajo vsi, ki so vpleteni v znanstveno raziskovalno komunikacijo (raziskovalci, knjižničarji, financerji raziskav, založniki), za namene:

- vrednotenja uspešnosti raziskovanja s pomočjo ugotavljanja vpliva objav posameznih raziskovalcev in raziskovalnih skupin,

- gradnje knjižničnih zbirk oz. za nakupe relevantnih virov,

- ugotavljanja uspešnosti izvajanja različnih raziskovalnih politik,

- ugotavljanja vpliva posameznih znanstvenih revij in drugih publikacij,

- iskanja relevantnih tematskih virov.

Uporabna vrednost bibliometrije, kot raziskovalne metode, se je izkazala v 1980-ih, ko:

- je bil priznan pomen njenih raziskovalnih izsledkov,

- je bilo ugotovljeno, da zakonitosti ne velja posploševati na vsa znanstvena področja enako in

- je bilo ugotovljeno, da ima poleg teoretičnega tudi izrazito aplikativen značaj (Bawden in Robinson, 2012; Tague-Sutcliffe, 1992).

Danes zasledimo vrsto bibliometrijskih raziskav in analiz, ki med drugim zajemajo:

- analizo citiranja,

- analize kazalnikov: dejavnik vpliva in sorodna merila - SNIP (Source Normalized Impact per Paper), SJR (Scientific Journal Rankings), IF (Impact Factor), ki merijo vpliv znanstvenih revij; Hirschev indeks ali h-indeks, ki meri vpliv posameznega raziskovalca,

- analize revij z vidika kakovosti, pokrivnosti področij, jezika izhajanja in dejavnosti uredništva,

- analize vpliva odprtega dostopa in e-publikacij,

- merjenje uspešnosti raziskovanja na osnovi objavljanja (na ravni držav, področij, različnih medijev),

- ugotavljanje interdisciplinarnosti in znanstvenega sodelovanja,

- ugotavljanja posledic raziskovalne politike in vrednotenja raziskovalne uspešnosti,

- analize patentov,
- analize bibliografskih zbirk, ki zbirajo podatke o objavah in njihovo odmevnost,

- altmetrije, kot skupek novih kazalcev odmevnosti raziskovalnega dela, predvsem na spletu.

Značilnost publiciranja na širšem in posameznih področjih že prinašajo mnogi viri. $V$ tem delu prikazujemo pregled objav in njihove ugotovitve za področja gozdarstva, lesarstva in papirništva. $V$ nadaljnjih poglavjih opisujemo način lociranja virov, ki so z uporabo bibliometrijskih metod že identificirali posebnosti in težave publiciranja na področjih gozdarstva, lesarstva in papirništva.

\section{METODE}

\section{METHODS}

Iskanja virov smo se lotili s pregledom štirih bibliografskih zbirk oz. informacijskih sistemov:

- Web of Science (WoS), multidisciplinarna bibliografska zbirka podatkov z indeksi citiranosti iz okrog 10.000 znanstvenih revij; prikazuje citathe indekse, znane tudi kot samostojne indekse za različna področja: SCI - Science Citation Index, SCIE - Science Citation Index Expanded, SSCI - Social Science Citation Index itd., ali kot pod skupnim imenom JCR - Journal Citation Report (izdajatelj je Thomson Reuters);

- Scopus, multidisciplinarna podatkovna zbirka izvlečkov in podatkov o citiranju (izdajatelj je založba Elsevier);

- CAB Abstracts, specializirana podatkovna zbirka za kmetijstvo, okolje, veterino, uporabno ekonomiko, živilstvo in prehrano in

- COBIB.SI, bibliografski-kataložna zbirka podatkov, ki vključuje zapise o objavah slovenskih avtorjev in o gradivu, ki ga hranijo slovenske knjižnice.

Najhitrejši pretok znanstvenih informacij poteka prek objav v obliki člankov (articles), zato smo se v vseh primerih omejili zgolj na tovrstne objave. Uporabili smo tudi spletni iskalnik Google Scholar, a le kot dopolnilo, saj pridobljeni podatki ne predstavljajo sistematičnosti in doslednosti pri zajemanju podatkov oz. znanstvenih objav (Aguillo, 2012; Bar-Ilan, 2008; Jacsò, 2010; Kousha in sod., 2011). Pri kreiranju iskalne strategije smo se oprli na že uporabljeno metodologijo Bar-Ilan (2008) v preglednem in večkrat citiranem članku o razvoju informetrije v 21. stoletju. Glede na naše potrebe in možnosti smo jo dopolnili z omejitvami na vede, ki so predmet naše raziskave, upoštevajoč tudi jezikovne posebnosti. 
Iskanje objav v zbirkah WoS (zajeti so citatni indeksi: SCI, SSCI, A\&HCI, CPCI-S, CPCI-SSH in ESCI), Scopus in $\mathrm{CAB}$ Abstracts je bilo opravljeno novembra $2016 \mathrm{v}$ načinih naprednega iskanja (advanced search) in v celotnem časovnem obsegu zbirk z omejitvijo na članke (articles). Numerični podatki o obsegu objav so prikazani v preglednici 1.

Za iskanje v zbirki WoS smo uporabili iskalno predpono TS (topic), v primeru Scopus z iskalno predpono ALL in v zbirki CAB Abstracts s predponami DE (descriptor index), TI (title), CW (CABICODES words), BT (broad terms), $\mathrm{SH}$ (subject headings) in AB (abstract).

Pri iskanju objav za področje bibliometrije smo uporabili iskalno sintakso 1 , za iskanje bibliometrijskih objav s področij gozdarstva, lesarstva in papirništva pa smo uporabili presek rezultatov iskalnih sintaks 1 in 2 .

Za pridobitev seznama virov, zavedenih v zbirki COBIB.SI, smo uporabili ukazno iskanje po predponi KW (ključna beseda) s slovenskimi in angleškimi izrazi. Zbirka je namenjena predvsem slovenskemu okolju in iz izkušenj vemo, da so zapisi nedosledno opremljeni s predmetnimi oznakami (bodisi v slovenščini bodisi v angleščini, ali oboje). Pri iskanju objav za področje bibliometrije uporabili iskalno sintakso 3, za iskanje bibliometrijskih objav s področij gozdarstva, lesarstva in papirništva pa smo uporabili presek rezultatov iskalnih sintaks 3 in 4.
Nabor zbranih virov je obsežen in, kolikor je to le mogoče, pregleden. $\mathrm{V}$ preglednici 1 prikazujemo tudi število objav glede na jezik, delež objav v angleščini in slovenščini.

Skupna značilnost objav je njihova velika razpršenost po revijah in področjih. Največji nabor virov ponuja zbirka Scopus, sledijo WoS in nato zbirka CAB Abstracts. Najmanj virov ponuja zbirka COBIB.SI, kar ni presenetljivo, saj je izmed vseh najbolj geografsko omejena.

Objave iz zbirke WoS smo podrobneje analizirali s pomočjo fasetnega iskanja in orodja WoS Results Analysis Tool. Približno 25 \% vseh zbranih objav je uvrščenih v kategorijo informacijskih in knjižničarskih znanosti (information science library science) in okoli $23 \%$ v kategorijo računalništva (computer science). Glede na podatke WoS po številu objav zbuja daleč največ pozornosti revija Scientometrics, kjer je objavljenih 10 \% vseh zbranih objav. Drugo uvrščena revija, Journal of Informetrics, prinaša bistveno manj, le $2 \%$ tovrstnih objav. Z omejitvijo iskanja po kategoriji WoS Forestry naštejemo 71 objav v 22 gozdarskih revijah. V kategoriji, ki najbolj neposredno vključuje lesarstvo in papirništvo (Material sciences, paper, wood), najdemo le 6 objav.

Iskalna sintaksa 1: Iskanje objav s področja bibliometrije v mednarodnih zbirkah

(informetric* OR bibliometric* OR webometric* OR "citation analysis" OR "citation analyses" OR "cocitation analysis" OR "cocitation analyses" OR "co-citation analysis" OR "co-citation analyses" OR "link analysis" OR "link analyses" OR "link structure" OR "self citation" OR "self citations" OR self-citation* OR "S\&T indicator*" OR citation map* OR citation visuali* OR "science policy" OR "research policy" OR "impact factor" OR h-index OR "h index" OR "Hirsch index" OR "patent analysis" OR "patent analyses" OR Zipf OR Bradford OR Lotka OR "collaboration network" OR "collaboration networks" OR "coauthorship networks" OR "coauthorship network" OR "co-authorship network" OR "co-authorship networks" OR altmetric* OR scientometric* OR cybermetric*)

Iskalna sintaksa 2: Omejitev iskanja objav s področij gozdarstva, lesarstva in papirništva v mednarodnih zbirkah (forest* OR wood* OR »paper science« OR pulp*)

Iskalna sintaksa 3: Iskanje objav s področja bibliometrije v zbirki COBIB.SI

KW=informetri* OR KW=bibliometri* OR KW=webometri* OR KW=faktor (W) vpliva OR KW=altmetr* OR KW=scientomet* OR KW=cybermetr* OR KW=citat OR KW=citati OR KW=citiranje OR KW=spletometr* OR KW=kibermetr* OR (KW=dejavnik (W) vpliva AND KW=(informetri* OR KW=bibliometri* OR KW=webometri* OR KW=altmetr* OR KW=scientomet* OR KW=cybermetr* OR KW=citat* OR KW=citiranje OR KW=spletometr* OR KW=kibermetr*))

Iskalna sintaksa 4: Omejitev iskanja na področja gozdarstva, lesarstva in papirništva v zbirki COBIB.SI

(KW=gozd* OR KW=lesar* OR KW=lesna* OR KW=papirniš* OR KW=celuloz*) 
Preglednica 1: Število objav bibliometrijskih raziskav v štirih izbranih zbirkah

\begin{tabular}{|l|c|c|c|c|}
\hline \multicolumn{1}{|c|}{ Članki / Articles } & WoS & Scopus & CAB Abstracts & COBIB.SI \\
\hline $\begin{array}{l}\text { objave s področja bibliometrije / publications from the sphere of } \\
\text { bibliometry }\end{array}$ & 23.860 & 34.301 & 13.021 & 554 \\
\hline $\begin{array}{l}\text { - angleški jezik / English language } \\
\text { - slovenski jezik / Slovenian language }\end{array}$ & $\begin{array}{c}22.158 \\
4\end{array}$ & $\begin{array}{c}32.322 \\
10\end{array}$ & $\begin{array}{c}3.233 \\
10\end{array}$ & 220 \\
\hline $\begin{array}{l}\text { objave s področja bibliometrije izbranih področij / publications } \\
\text { from the sphere of bibliometry of selected spheres }\end{array}$ & 351 & 4.317 & 538 & 11 \\
\hline $\begin{array}{l}\text { - članki, angleški jezik / articles, English language } \\
\text { - članki, slovenski jezik / articles, Slovenian language }\end{array}$ & $\begin{array}{c}340 \\
0\end{array}$ & $\begin{array}{c}4.204 \\
0\end{array}$ & 411 & 3 \\
\hline
\end{tabular}

\section{RAZISKOVALNI VIDIKI OBJAV}

\section{PUBLICATIONS' RESEARCH ASPECTS}

Večina zajetih bibliometrijskih objav s področja gozdno-lesne verige se ukvarja $\mathrm{z}$ ugotavljanjem trenutnih raziskovalnih trendov. Bibliometrija je $\mathrm{v}$ teh primerih uporabljena kot metoda, vendar nam rezultati ne povedo veliko o samih značilnosti publiciranja. Manjši del objav prinaša zanimive zaključke o objavljanju na področjih gozdarstva, lesarstva in/ali papirništva in jih lahko delimo na nekaj vidikov:

- vidik interdisciplinarnosti v gozdarstvu; predvsem ustvarjanje seznamov naslovov revij in iskanja možnosti objavljanja znanstvenih člankov;

- vplivi različnih dejavnikov na odmevnost objav;

- vidik raziskovanja sodelovanja med teoretiki in praktiki v gozdno lesni verigi in prenos znanja iz znanosti v prakso;

- ugotavljanje produkcije posameznih raziskovalnih skupin in držav.

Pri vrednotenju bibliometrijskih kazalcev je pomembno, da med seboj primerjamo področja, ki imajo podobne vzorce objavljanja. Različni šifranti omogočajo enotno in mednarodno primerljivo statistično spremljanje posamezne raziskovalne dejavnosti in vlaganj $\mathrm{v}$ raziskave in razvoj z namenom boljšega razumevanje težav posameznega področja. Šifranti znanosti in zbirke podatkov različno umeščajo naša tri področja (Klasifikacije, šifranti, 2016):

- Javna agencija za raziskovalno dejavnost v RS (ARRS) vsa tri področja uvršča v področje biotehnike (»Klasifikacija ARRS«);

- evropska klasifikacija raziskovalne dejavnosti (»CERIF-CERCS«) gozdarstvo uvršča v agronomijo znotraj biomedicinskih ved; lesarstva in papirništva oz. »lesno, kašno in papirno tehnologijo« pa uvršča med transportne tehnologije znotraj tehnoloških ved;

- klasifikacija področij znanosti in tehnologije (»FOS 2007 «) uvršča gozdarstvo v kmetijske vede, medtem ko lahko lesarstvo in papirništvo klasificiramo
Table 1: Number of bibliometric research publications in four selected databases

v sklop Materiali znotraj tehniških in tehnoloških ved;

- zbirka WoS vsa tri področja uvršča v Science Citation Index (SCI); ločuje kategoriji gozdarstvo (KA forestry) in materiali, papir in les (PJ - materials science, paper \& wood). Ob tem ne smemo zanemariti, da so nekatera področja mejna in jih lahko uvrstimo tudi v druge kategorije (npr. PK - materials science, ceramics, PM - materials science, multidisciplinary, PZ - metallurgy \& metallurgical engineering, QF materials science, characterization \& testing, QG materials science, coatings \& films, QH - materials science, composites, QJ - materials science, textiles, OA - instruments \& instrumentation, UB - physics, applied in UY - polymer science);

- Zbirka SCOPUS ločuje kategoriji »Forestry«, kamor uvršča gozdarstvo in »Materials Science«, ki zajema širše področje, med drugim tudi lesarstvo in papirništvo.

Posamezna področja znanosti se redko prikazujejo samostojno. Obstoječi šifranti neenako in včasih diskutabilno uvrščajo različna področja v posamezne vede. Na področju gozdarstva, lesarstva in papirništva je področje gozdarstva samostojno predstavljeno v večini šifrantov, medtem ko to ne drži za področji lesarstva in papirništva. Lesarstvo in papirništvo sta izvzeti oz. sta del širših ved, kar identifikacijo objav in primerjalne bibliometrijske raziskave (iz različnih virov) otežuje.

\section{INTERDISCIPLINARNOST IN VPLIV REVIJ}

\section{INTERDISCIPLINARITY AND JOURNAL IMPACT}

Večina analiz poudarja interdisciplinarnost področja. Ta se kaže že pri revijah, ki so po klasifikacijah gozdarske, a politika objavljanja široko interpretira gozdarstvo in tako revije večinoma pokrivajo vsa mejna področja, od ekologije do agronomije in ekonomije. Večinoma so »čiste« gozdarske revije, brez interdisciplinarnih člankov, v manjšini (Malesios in Arabatzis, 2012). Leta 2008 je bil sestavljen in objavljen seznam 180 revij s področja gozdarstva, ki vidno prispeva- 
Preglednica 2: Zastopanost področij v različnih klasifikacijah znanosti (Klasifikacije, šifranti, 2016)
Table 2: Representation of spheres in various classifications of sciences (Klasifikacije, šifranti, 2016)

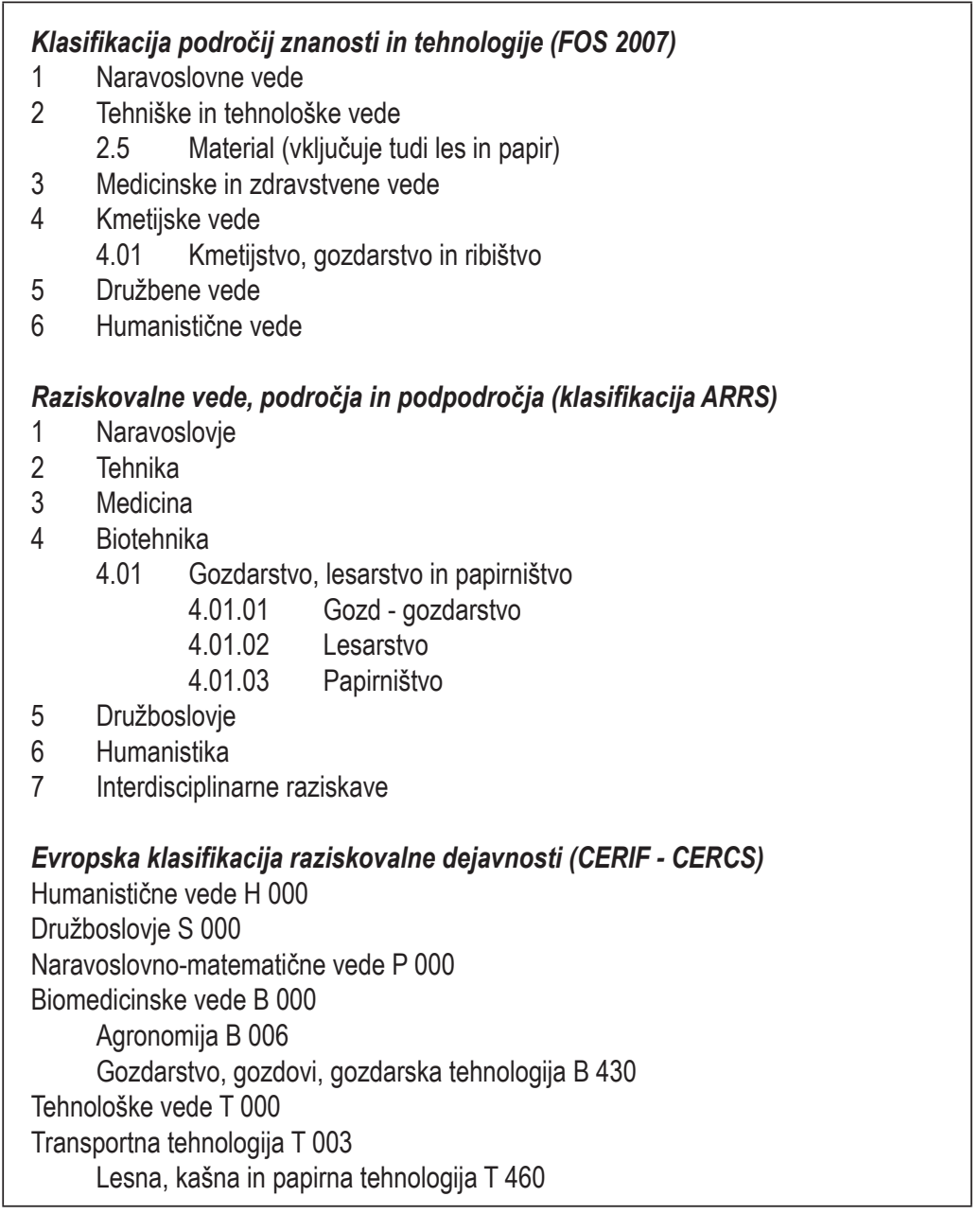

jo $\mathrm{k}$ razvoju te stroke in so odmevne $\mathrm{v}$ mednarodnih zbirkah. Seznam je bil pripravljen kot pomoč raziskovalcem pri iskanju ustreznih revij, s katero bi avtorji dosegli svojo ciljno publiko (Vanclay, 2008). Na seznam ni uvrščena nobena slovenska gozdarska revija, saj je izbor temeljil na vključenosti revij v zbirke WoS, Database Forest, Ulrich's Periodical Directory, JournalSeek, Metla's Virtual Forestry Library in Google Scholar, kjer pa slovenske revije $\mathrm{v}$ tistem času niso bile zastopane. Zajete so le revije, ki objavljajo pretežno gozdarsko tematiko.

Analiza revij s področja gozdarstva kaže na relativno veliko razliko v odmevu, ki ga meri dejavnik vpliva. V obdobju 2006-2010, ko je bilo v zbirko WoS uvrščenih med 35 in 54 naslovov revij, sta se dve reviji (Forest Ecology and Management, Canadian Journal of Forest Research) izrazito razlikovali od drugih, in sicer po visokem odmevu in visokem številu objav. Sledi skupina štirih revij, ki še imajo relativno visok odmev, a manjše število objav; preostale revije pa sestavljajo tretjo skupino revij. Hkrati avtorji ugotavljajo tudi visoko korela- cijo med višino dejavnika vpliva in številom objavljenih člankov v posamezni reviji (Bojović in sod., 2014). Formula izračunavanja faktorja vpliva (število citatov na število citiranih člankov) daje mnogim revijam visok vpliv, četudi imajo majhno število objav.

Drug vidik interdisciplinarnosti izhaja iz analiz objav raziskovalnih rezultatov. Te so za področje gozdarstva porazdeljene po revijah drugih sorodnih področjih in zato objave gozdarskih raziskav najdemo tudi v revijah družboslovnih področij, s področij ekonomije, sociologije, političnih in pravnih ved (Klenk in sod., 2010). Podobno ugotavljajo tudi Dreyer in sod. (2014) in dodajajo, da je le $10 \%$ znanstvenih člankov z gozdarsko tematiko dejansko objavljenih $v$ gozdarskih revijah. To, da raziskovalci objavljajo izsledke gozdarskih raziskav v drugih revijah, je po njegovem mnenju posebnost tega področja.

Na podlagi zbirke CAB Abstract je za članke slovenskih avtorjev s področij kmetijstva in ved o življenju ugotovljeno prepletanje z družboslovnimi tematikami, sledi ekonomika, gozdarstvo, lesarstvo, naravni viri 
(npr. voda, meteorologija, onesnaževanje), zdravje, biologija in prehrana ljudi, živilstvo, rastlinska proizvodnja in varstvo ter živalska proizvodnja (Bartol in Hočevar, 2011). Novejša analiza objav slovenskih raziskovalcev z različnih področij biotehnike za obdobje 1996 do 2014 je pregledala 779 člankov, objavljenih v 286 znanstvenih revijah, indeksiranih v zbirki WoS. Objave so razpršene v 97 različnih WoS- kategorijah. Ugotavlja, da se članki slovenskih avtorjev s področja gozdno lesne verige najbolj pogosto sicer pojavijo $\mathrm{v}$ kategorijah gozdarstvo (forestry) in materiali, papir in les (materials science, paper \& wood), toda tem sledi botanika (plant sciences), ki je del naravoslovja. Zanemarljive niso tudi kategorije znanosti o okolju (environmental sciences) ter ekologija (ecology), pa tudi kemija na področju kmetijstva (Agriculture chemistry), ker je prav tako naravoslovna kategorija v WoS (Bartol in sod., 2016).

Podobna analiza znanstvene produkcije in objav za področje gozdarstva je bila opravljena za Italijo in na podlagi podatkov iz zbirk WoS in SCOPUS. Objave italijanskih avtorjev na področju gozdarstva naj bi predstavljale le $0,5 \%$ celotne italijanske znanstvene produkcije. Hkrati pa analiza objav kaže na veliko število objav raziskovalcev s področja gozdarstva $v$ revijah z drugih znanstvenih področij (Chirici, 2012). Tudi druge analize, z drugačnimi metodološkimi pristopi, ugotavljajo podobno. Za gozdarstvo je tako značilno veliko število objav v revijah drugih področij. Izraz "gozdarstvo« (»forestry«) se v zbirki Scopus pojavlja v 1.412 člankih, ki so objavljeni v kar 389 revijah, od katerih večina ni s tega področja (Vanclay in Bornmann, 2012).

\section{ODMEVNOST OBJAV}

\section{PUBLICATION IMPACT}

Interdisciplinarnost ima velik vpliv na odmevnost, ki jo raziskujemo na podlagi citiranja objav. Analiza citatov člankov, objavljenih v reviji Forestry Science, ugotavlja, da so članki, ki so citirali članke iz več revij različnih področij, bili pogosteje citirani (Stelle in Stier, 2000). Značilnosti odmevnosti objav, torej število citatov, je za revije s področij gozdno lesne verige primerljiva $z$ večino drugih znanstvenih področij. Kot pomemben vpliv na višjo odmevnost je poudarjeno soavtorstvo, še posebej mednarodno, ki lahko pomembno vpliva tudi na možnost objave v vplivnejših revijah (Vanclay, 2012).

$\mathrm{V}$ analizi štirih vodilnih kitajskih znanstvenih revij so ugotovili, da avtorji večinoma prihajajo iz univerzitetnega in raziskovalnega okolja. Objave avtorjev, ki prihajajo iz »prakse«, iz lokalnih gozdarskih organiza- cij in podjetij, predstavljajo le $17,2 \%$ in še te so večinoma pisane $\mathrm{v}$ soavtorstvu $\mathrm{z}$ raziskovalci $\mathrm{z}$ univerz ali iz raziskovalnih ustanov (Perez in sod., 2004). Novejša kanadska raziskava ugotavlja naraščanje objav zaposlenih v kanadski javni gozdarski službi (Canadian Forest Service), a hkrati poudari številne univerze kot ključna vozlišča pri objavi rezultatov javno podprtih raziskav (Bonnell, 2012).

MacLean (2008) opozarja na neizvedljivost istočasne kakovostne vpetosti avtorjev v raziskovanje, poučevanje, publiciranje in v prenos v prakso. Zagovarja, da je malo rezultatov, ki bi jih bilo možno objaviti v visoko ugledni znanstveni reviji in hkrati z njimi spreminjati trenutne procese v gozdarstvu in politiki. Danes je znanstvena komunikacija nujna z vidika zadoščanja merilom financerjev, a če je ciljna publika gozdna industrija ali politika, znanstveni članki niso primeren način diseminacije informacij. Kot možno rešitev predlaga kratka poročila na do dveh straneh s poudarki na raziskovalnem vprašanju, ugotovitvah in razlago, kaj ugotovitve pomenijo za prakso. Za območje Severne Amerike zato identificira dve skupini revij, takšne, ki so primerne za diseminacijo raziskovalnih dosežkov (znanstvene revije različnih področij), in druge, ki so namenjene praktikom. Iz vidika mednarodnosti ni odveč izpostaviti, da gre $\mathrm{v}$ tem primeru za revije $\mathrm{v}$ angleščini in da so vse indeksirane v zbirkah WoS in Scopus.

Število citatov se povečuje z raziskovalno starostjo raziskovalcev (čas od pridobitve naziva doktorja znanosti) (Copenheaver in sod., 2010; Slyder in sod., 2011). Raziskava na primeru dendrokronologov pa tudi ugotavlja, da materni jezik (angleški ali drugi), trenutna zaposlitev (vladne ustanove ali univerza) in spol prvega avtorja ne vplivajo na število pridobljenih citatov (Copenheaver in sod., 2010). Isti avtorji na področju dendrokronologije ugotavljajo visoko produktivnost avtoric in hkrati visok delež soavtorstva avtoric z moškimi kolegi.

Mnoge raziskave se osredotočajo na vpliv jezika objave na njeno odmevnost ali nevidnost v svetovnem merilu in ugotavljajo prednosti objavljanja $\mathrm{v}$ angleškem jeziku, tako za raziskovalca kot za revijo. Čilska raziskava tako navaja večanje deleža špansko govorečih raziskovalcev, ki razumejo angleški jezik. Navaja tudi poskus dviga mednarodne odmevnosti (citiranja) čilenskih objav z zavestnim objavljanjem v vzporedni dvojezični obliki. Četudi mnoge objave poudarjajo pomanjkanje neangleških revij v zbirki WoS, Meho in Yang (2007) navajata, da vključevanje revij drugih jezikov WoS ne viša njihove uporabe oz. citiranosti. Avtorji naj bi citirali le 1,14 \% (v primeru zbirke WoS) oz. 0,70 
$\%$ (v primeru zbirke Scopus) objav v drugih jezikih.

Avtorji iz neangleško govorečih območij in še bolj uredništva neangleških revij in revij, ki pokrivajo majhna znanstvena področja, se srečujejo $\mathrm{z}$ dvema mnogokrat nasprotujočima si ciljema: zadostno število objav v domačem jeziku (s katerim se razvija strokovna terminologija jezika in popularizira stroko $v$ domači javnosti) in mednarodna odmevnost. Objava v reviji, ki pokriva majhno znanstveno področje ali ne objavlja $\mathrm{v}$ angleškem jeziku, ne more doseči mednarodnega kroga bralcev in posledične mednarodne odmevnosti. Tako se uredništva neangleških revij spopadajo z zaskrbljujoče majhnim številom prejetih člankov in njihovo vprašljivo kvaliteto. Avtorji običajno članke v te revije pošljejo, če so članki zavrnjeni v bolj uglednih revijah ali pa je njihova tematika geografsko zelo omejena. $V$ tem pogledu je pomembna hitrost odziva uredništva na spremembe v znanstveni komunikaciji, učinkovito predstavljanje potencialnim avtorjem in bralcem in učinkovito višanje vidnosti revije (npr. odprt dostop, vključenost v mednarodne zbirke, sezname). Da je količina objav v domačem jeziku majhna in da je objavljanje v domačem jeziku pomembno, nakazujejo posamezni evalvacijski poskusi. Univerza v Ljubljani z novimi habilitacijskimi merili motivira objave $\mathrm{v}$ slovenskem jeziku z zahtevo po takšnih objavah (Čistopis meril ..., 2016: člen 55, 59, 63).

Raziskovalci opozarjajo na specifike pri objavljanju v posameznih znanstvenih vedah in posledično slabše pozicije pri že omenjenem pridobivanju raziskovalnih sredstev. V primeru slovenskega gozdarstva poročajo tudi o pomanjkanju domačih vlaganj v raziskave, kar raziskovalce vodi v pridobivanje sredstev Evropske unije, kar pa posledično prinaša nepovezanost vsebine in ciljev raziskav z iskanjem rešitev za slovenski gozd, lokalno gozdarstvo, lesarstvo ali papirništvo (Kraigher H. in sod., 2015).

\section{RAZPRAVA}

\section{DISCUSSION}

Iz širokega nabora zbranih virov smo v pregled objav vključili objave, ki opisujejo značilnosti objavljanja na področjih gozdarstva, lesarstva in papirništva. Ugotavljamo, da je objav, ki prinašajo ugotovitve o značilnostih publiciranja v gozdarstvu, kar nekaj, skoraj nič pa s področij lesarstva in papirništva. To je lahko posledica bodisi večje povezanosti področij z drugimi vedami bodisi majhno število raziskovalcev in inštitucij, ki bi pokrivale specifično področje, lahko pa nakazujejo tudi raziskovalno nerazvitost teh področij. Povzeli smo tudi relevantne ugotovitve, ki se sicer nanašajo na širše področje biotehnike, agronomije ali kmetijskih ved. Zaradi navedenega je malo objav, ki bi prinašale ugotovitve ali primerjave objavljanja raziskovalcev na nivoju ustanov, držav in njihovo sodelovanje. Veljalo bi tudi podrobneje raziskati, kako interdisciplinarnosti področij (predvsem lesarstva in papirništva) vplivajo na publiciranje.

Kot skupno značilnost predstavljenih virov je treba posebej omeniti metodologijo oz. nabor analiziranih virov. Bibliometrijske raziskave večinoma analizirajo članke, objavljene $\mathrm{v}$ znanstvenih (recenziranih) revijah, ki so vključene $v$ mednarodne zbirke, kot sta WoS in Scopus. Kljub mnogim kritikam je zbirka WoS širše uporabljena, predvsem ker zajema podatke za daljše časovno obdobje. Zbirka Scopus v zadnjem času konkurira predvsem z boljšim pokrivanjem nekaterih znanstvenih področij, tehnike, družboslovja in humanistike (Bartol in sod., 2014). Zbirki zajemata predvsem znanstvene članke in zato običajno raziskave ne ugotavljajo prenosa raziskovalnih dosežkov v prakso ali sledljivosti vpliva raziskovalnih dosežkov na razvoj prakse in ugotavljanje njihovega vpliva na razvoj družbe. Po MacLeanu (2008) je v gozdarstvu tudi nemogoče z eno objavo zadostiti vsem pogojem, raziskovalci pa so časovno in finančno omejeni. Raziskovalci morajo objaviti zadovoljivo število kakovostnih objav, da izpolnijo pričakovanja evalvacijskih procesov, tako $\mathrm{z}$ vidika financerjev znanstvenih raziskav kot tudi z vidika vrednotenja dela posameznega raziskovalca. Ker objave, namenjene implementaciji znanstvenih dosežkov v prakso, pomenijo malo ali nič v evalvacijskih procesih, raziskovalci niso dovolj motivirani za objavljanje strokovnih del. Poleg tega priprava strokovnih objav zahteva drugačen pristop, saj je treba vsebino prilagoditi ciljnemu bralcu. Bralcem, ki niso raziskovalci in jih znanstveni vidiki ne zanimajo, je treba poudariti zaključke in priporočila, predvsem pa naj bi bila objava pisana v domačem jeziku.

Evalvacijski sistemi in pravila lahko pomembno vplivajo na način objavljanja. Poudarjanje pomena količine nad kakovostjo (kot se je dogodilo v nekaterih evalvacijskih sistemih, npr. v Avstraliji) lahko privede do občutnega povišanja števila objav, četudi v manj uglednih in odmevnih revijah (Vanclay, 2012). Odmevnost, merjena s številom citatov, je tako praviloma slabša.

Usmeritev evalvacijskih postopkov, ki dajejo veliko prednost mednarodnim znanstvenim objavam in zaznavanju njihovega mednarodnega vpliva, je za aplikativna področja znanosti problematična. Če se pri vrednotenju prijavljenih raziskovalnih projektov daje večji pomen predhodnim objavam prijaviteljev (raziskovalcev), ti projekti v takšnih procesih niso konku- 
renčni in dolgoročno ne moremo pričakovati razvoja področja. Za razvoj aplikativnih področij je treba zagotoviti prenos dosežkov v prakso, kar pa ni izvedljivo brez aktivne vloge gospodarstva. $\mathrm{V}$ primeru nerazvite industrije, še posebej če panogo država oceni kot strateško, bi morala država nastopiti kot vzpodbujevalec vlaganja v razvoj in spodbujati sodelovanje na ravni industrija - raziskovalne ustanove. Le tako bi se raziskovalci lahko bolje povezali s sodelavci v praksi, dobili potrebna aktualna raziskovalna vprašanja in zagotovili prenos dosežkov v prakso, čemur bi sledil razvoj industrije in z njo povezanih dejavnosti.

\section{ZAHVALA}

\section{ACKNOWLEDGEMENTS}

Raziskavo je delno sofinancirala Evropska unija, in sicer iz Evropskega socialnega sklada. Sofinanciranje se izvaja v okviru Operativnega programa razvoja človeških virov za obdobje 2007-2013, 1. Razvojne prioritete Spodbujanje podjetništva in prilagodljivosti; prednostne usmeritve 1. 3: Štipendijske sheme.

Objava je nastala v okviru projekta »Presoja raziskovalnih skupin na področju kmetijstva, gozdarstva, ribištva in živilstva v Sloveniji in v primerljivih državah«, financiranega s strani Javne agencije za raziskovalno dejavnost Slovenje (V5-1425).

Zahvaljujeva se recenzentom za natančen pregled članka in tehtne pripombe.

\section{VIRI}

\section{REFERENCES}

Acuña E., Espinosa M., Cancino J. 2013. Paper-based productivity ranking of Chilean forestry institutions. Bosque, 34, 2: 211-219

Aguillo I. F. 2012. Is Google Scholar useful for bibliometrics? A webometric analysis. Scientometrics, 91, 2: 343-351

Bar-Ilan J. 2008. Informetrics at the beginning of the 21 st century - a review. Journal of Informetrics, 2, 1-52

Bartol T., Hočevar M. 2011. Topics related to social sciences by authors from Slovenia in agriculture-and-life-sciences database CAB Abstracts. Acta Agriculturae Slovenica, 97, 3: 197-205

Bartol T., Budimir, G., Dekleva-Smrekar D., Pusnik M., Juznic P. 2014. Assessment of research fields in Scopus and Web of Science in the view of national research evaluation in Slovenia. Scientometrics, 98, 2: 1491-1504.

Bartol, T., Budimir, G., Juznic, P., Stopar, K. 2016. Mapping and classification of agriculture in Web of Science: other subject categories and research fields may benefit. Scientometrics, 109, 2: 979-996.

Bawden D., Robinson L. 2012. Introduction to information science. London, Facet publishing: XXV, 351 str.

Bojović S., Matić R., Popović Z., Smiljanić M., Stefanović M.in sod. 2014. An overview of forestry journals in the period 2006-2010 as basis for ascertaining research trends. Scientometrics, 98,2 : 1331-1346

Bonnell B. 2012. Trends in research and collaboration in the Canadian Model Forest Network, 1993-2010. The Forestry Chronicle, 88, 3: 274-282
Chirici G. 2012. Assessing the scientific productivity of Italian forest researchers using the Web of Science, SCOPUS and SCIMAGO databases. Iforest, 5, 101-107

Copenheaver C. A., Goldbeck K., Cherubini P. 2010. Lack of gender bias in citation rates of publications by dendrochronologists: what is unique about this discipline? Tree-Ring Research, 66, 2: 127-133

Čistopis meril za volitve v nazive visokošolskih učiteljev, znanstvenih delavcev ter sodelavcev Univerze v Ljubljani, z dne 27. 9. 2016. https://www.uni-lj.si/mma/CistopisMeril2792016/ 2016101911015269/ (15. 10.2016)

Dreyer E., Peiffer M., Bontemps JD, Leban, JM. 2014. Annals of Forest Science changes its scope and complies with green open access rules. Annals of Forest Science, 71, 4: 425-426

Jacsò P. 2010. Pragmatic issues in calculating and comparing the quantity and quality of research through rating and ranking of researchers based on peer reviews and bibliometric indicators from Web of Science, Scopus and Google Scholar. Online Information Review, 34, 6: 972-982

Klasifikacije, šifranti. 2016. http://www.arrs.gov.si/sl/gradivo/sifranti (2. 5.2016)

Klenk N. L., Dabros A., Hickey G. M. 2010. Quantifying the research impact of the Sustainable Forest Management Network in the social sciences: a bibliometric study. Canadian Journal of Forest Reserch, 40, 11: 2248-2255

Kousha K., Thelwall M., Rezaie S. 2011. Assessing the citation impact of books: The role of Google Books, Google Scholar, and Scopus. Journal of the American Society for Information Science and Technology, 11: 2147-2164

Kraigher H., Humar M., Peteh M., Simončič P. 2015. Znanost in znanje o gozdu, gozdarstvu in lesarstvu $=$ Science and knowledge of forests, forestry and woodworking. V: Gozd in les: Slovenski gozd za Slovenijo $=$ Forest and wood: Slovenian forest for Slovenia. Zupančič M. (ur.). Ljubljana, Gozdarski inštitut Slovenije, Založba Silva Slovenica: $10-18$

MacLean D. A. 2008. Making sense of the "forestry research game" at universities. The Forestry Chronicle, 84, 4: 543-547

Malesios C., Arabatzis G. 2012. An evaluation of forestry journals using bibliometric indices. Annals of Forest Science, 55, 2: 147 . 164

Meho L. I., Yang K. 2007. A new era in citation and bibliometric analyses: Web of Science, Scopus, and Google Scholar. Journal of the American Society for Information Science and Technology, 58, 2105-2125

Perez M. R., Fu M., Xie J., Yang X., Belcher B. 2004. The relationship between forest research and forest management in China: an analysis of four leading Chinese forestry journals. International Forestry Review, 6, 3/4: 341-345

Slyder J. B., Stein B. R., Sams B. S., Walker D. M., Beale B. J.in sod. 2011. Citation pattern and lifespan: A comparison of discipline, institution, and individual. Scientometrics, 89, 3: 955-966

Stelle T. S., Stier J. C. 2000. The impact of interdisciplinary reserch in the environmental sciences: a foresty case study. Journal of American Society for Information Science, 51, 5: 476-484

Tague-Sutcliffe J. 1992. An introduction to informetrics. Information Processing \& Management, 28, 1: 1-3

Vanclay J. K. 2008. Ranking forestry journals using the h-index. Journal of Informetrics, 2, 4: 326-334

Vanclay J. K. 2012. Publication patterns of award-winning forest scientists and implications for the Australian ERA journal ranking. Journal of Informetrics, 6, 1: 19-26

Vanclay J. K., Bornmann L. 2012. Metrics to evaluate research performance in academic institutions: a critique of ERA 2010 as applied in forestry and the indirect $\mathrm{H}-2$ index as a possible alternative. Scientometrics, 91, 3: 751-771 